\title{
World Journal of Pediatric Surgery \\ Incidental finding of intra-abdominal hemangioma in an infant presenting with intestinal obstruction: a case report
}

\author{
Parveen Kumar, ${ }^{1}$ Arti Khatri (10 , ${ }^{2}$ Somshankar Chowdhury, ${ }^{2}$ Nidhi Mahajan, ${ }^{2}$ \\ Geetika Mathur ${ }^{1}$
}

To cite: Kumar P, Khatri A, Chowdhury S, et al. Incidental finding of intra-abdominal hemangioma in an infant presenting with intestinal obstruction: a case report. World JnI Ped Surgery 2022;5:e000335. doi:10.1136/wjps-2021-000335

Received 30 June 2021 Accepted 25 0ctober 2021

Check for updates

(C) Author(s) (or their employer(s)) 2022. Re-use permitted under CC BY-NC. No commercial re-use. See rights and permissions. Published by BMJ.

${ }^{1}$ Pediatric Surgery, Chacha Nehru Bal Chikitsalaya, New Delhi, India

${ }^{2}$ Pathology, Chacha Nehru Bal Chikitsalaya, New Delhi, India

Correspondence to Dr Arti Khatri; a.khatri2008@ gmail.com
Hemangiomas are the most common benign vascular tumours of the pediatric age group. They originate from embryonic remnants of unipotent angioblastic cells. The liver is the most common site for hemangioma in the abdomen. ${ }^{1}$ The prevalence of hepatic hemangioma $(\mathrm{HH})$ varies from $1 \%$ to $20 \%$ in the general population, and it is two to five times more common in women. $\mathrm{HH}$ is usually detected incidentally and shows no symptoms; therefore, most of the time it does not require any treatment. ${ }^{2}$ However, hemangioma may sometimes occur at the atypical location and present with unusual clinical manifestations within the abdominal cavity. Due to these reasons, it leads to diagnostic confusion, resulting in their inadvertent surgical excision. ${ }^{12}$ We present here a case of intra-abdominal hemangioma in an infant who presented with the signs and symptoms of intestinal obstruction.

A 4-month-old male infant presented to the pediatric surgery emergency department with excessive crying and bilious vomiting for 2 days. There was a history of associated lowgrade fever, which responded to local medications (syrup paracetamol). At presentation, he had a pulse rate of $120 / \mathrm{min}$ and a respiratory rate of $28 / \mathrm{min}$. Skin turgor was maintained with no dehydration. Abdominal examination revealed a soft abdomen with mild upper abdomen fullness without any tenderness or lump formation. Ultrasound of the abdomen showed an ill-defined lump in the right lumbar region measuring about $2.4 \times 1.6 \mathrm{~cm}$, and suspicion of intussusception was raised. There was no free fluid in the peritoneal cavity. X-ray of the abdomen showed air-fluid levels with dilated bowel loops (figure 1A). Laboratory investigations showed hemoglobin $141 \mathrm{~g} / \mathrm{L}$ $(95-141 \mathrm{~g} / \mathrm{L})$, total leukocyte counts of $14.2 \mathrm{x}$ $10^{9} / \mathrm{L}\left(6-17.5 \times 10^{9} / \mathrm{L}\right)$, and $\mathrm{C}$ reactive protein of $18 \mathrm{mg} / \mathrm{L}(2-5 \mathrm{mg} / \mathrm{L})$. The rest of the parameters were within normal limits. There was no significant personal and family history. For the initial 24 hours, the patient was kept nil per oral, given intravenous antibiotics and maintenance fluids. However, the patient had similar findings on repeat imaging. Exploratory laparotomy was planned owing to suspicion of intussusception. Laparotomy revealed normal-looking bowel without any intussusception or malrotation. There were few congenital/adhesive bands, one of which was encircling proximal ileum, causing partial obstruction. The bands were converging to a yellowish color structure, which was adhered to the liver margin (figure 1B). These bands, along with yellowish structure, were cut using harmonic in flush with Glisson's capsule at the liver margin and were sent for histopathological examination (figure 2A). On gross examination, the yellowish structure measured $1.5 \times 1.3 \times 0.5 \mathrm{~cm}$. The microscopic examination showed a moderately cellular lesion composed mainly of capillaries with variable-sized and dilated vascular channels. The vascular channels were lined by flattened endothelial cells, highlighted on CD34 immunostaining (figure 2B). Findings were consistent with involuting hemangioma. The child was asymptomatic in the postoperative period and was doing well in the follow-up period at 2 years.

Hemangiomas are benign vascular tumours, the most common benign softtissue neoplasm of the pediatric age group, that grow by endothelial cell proliferation. Surgeons and pathologists must differentiate hemangiomas from vascular malformations, which are structural anomalies of vessels. ${ }^{34}$ The prevalence of hemangioma is around $12 \%$ in less than 1 year of age. Hemangiomas are more commonly seen with premature infants, increased maternal age, female sex, white race, and twins. ${ }^{45}$ Based on the size of vessels on histopathology, hemangioma is divided into capillary, cavernous, and mixed type. ${ }^{5}$

$\mathrm{HH}$ shows growth and involution patterns similar to cutaneous hemangioma. The 

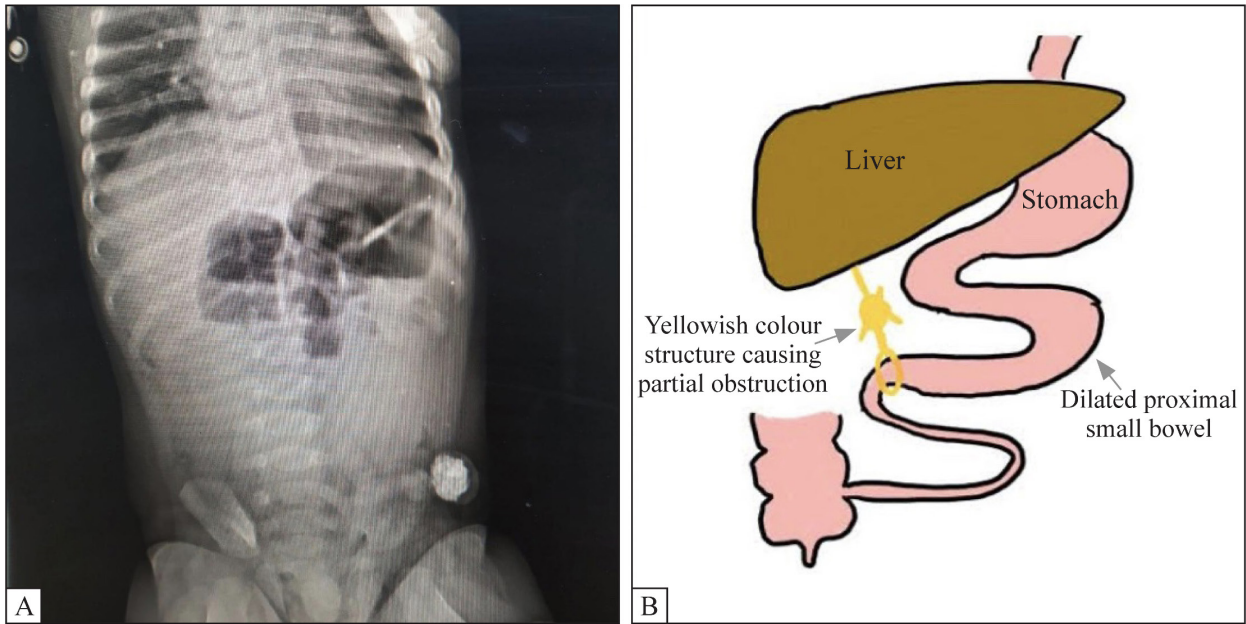

Figure 1 (A) X-ray of the abdomen showing proximal bowel dilated loops with air-fluid levels. (B) Schematic diagram to show intraoperative findings (illustrated by Parveen Kumar and drawn by Arti Khatri).

mainstay of hemangioma treatment is to wait and watch as the majority follow a natural course of proliferation, phase of involution, and finally regress without any active management. HH commonly shows no symptoms and is often incidentally detected. ${ }^{6}$

The most common symptom of abdominal hemangioma (when symptomatic) is abdominal pain and very rarely it can cause bleeding, rupture, and pressure symptoms due to compression of adjacent organs. Also, very few patients have complications secondary to $\mathrm{HH}$, such as high-volume shunting, intra-abdominal bleeding, pressure symptoms on other organs, congestive heart failure, and Kasabach-Merritt syndrome. KasabachMerritt syndrome is characterized by hemolytic anemia, thrombocytopenia, prolonged prothrombin time, and hypofibrinogenemia. Thus, above are the findings to go for active management of hemangioma. However, the majority of these lesions do not require any surgical excision. $^{278}$

Compared with vascular malformations on microscopy, hemangiomas show plump endothelial cells, endothelial mitoses, and the absence of intralesional nerve bundles. However, hemangiomas can show flattened endothelial lining and variable-sized dilated blood vessels in the
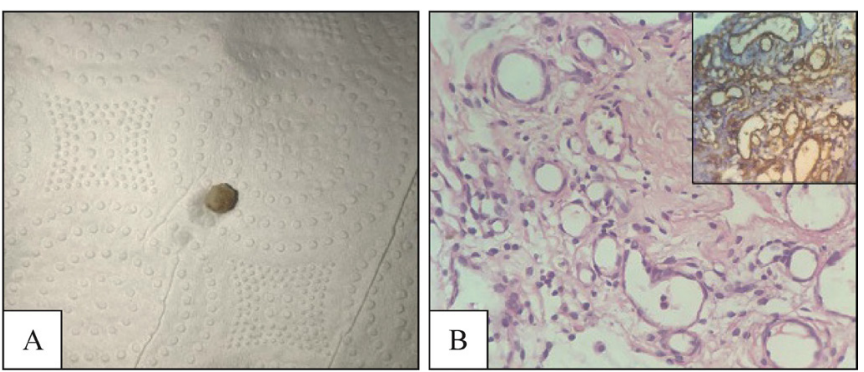

Figure 2 (A) Gross photomicrograph of yellowish colored structure. (B) Microscopy examination shows variable-sized vascular channels (predominantly capillaries) lined with flat endothelial cells (H\&E, 400x). Inset showing endothelial cells showing CD34 positivity (immunohistochemistry, 400x). involution phase. ${ }^{9}$ The role of immunohistochemistry comes in the capillary-predominant vascular lesion. Similar to the vascular malformation, the large draining blood vessels can be seen in involuting hemangioma and in congenital hemangioma. CD34 shows immunoreactivity for vascular endothelial cells. The other immunostains, such as glucose transporter protein isoform-1, are useful sensitive and specific immunostaining in delineating the endothelial cells of infantile hemangioma and in delineating the intralesional nerve bundles of vascular malformations. WT-1 is a tumour suppressor gene, which encodes for a transcription factor that shows cytoplasmic immunoreaction in hemangiomas, whereas vascular malformation is WT-1 negative. ${ }^{89}$

The treatment options are many; however, no standard algorithmic approach has been determined to date. Many asymptomatic hemangiomas undergo spontaneous regression in the first year of life. In the management of symptomatic hemangiomas, pharmacotherapy in the form of beta-blockers, steroids, and interferons is preferred over surgery and laser ablation nowadays. The latter ones are used in complex cases. ${ }^{69}$

In the current case, although the preoperative and intraoperative diagnosis of the hemangioma was not made, surgical excision was done for the diagnostic purpose. The initial and later ultrasounds did not pick up hemangioma, as it may have been already in the involution phase. No abnormality was detected in the liver on scans. MRI is a diagnostic aid to diagnose hemangiomas. However, we believe that it would not have been helpful in the index case, given the already involuting nature of the lesion. In addition, MRI does not detect adhesive/ fibrous bands often in such cases.

This report documents our experience with a case of incidental involuting hemangioma on the surface of the liver with adhesive bands in a 4-month-old infant with signs and symptoms of intestinal obstruction and with a provisional clinical diagnosis of intussusception. Knowledge of atypical location and presentation of 
hemangioma as an atypically localized small mass in the abdomen during an examination, imaging and intraoperatively can avoid inadvertent diagnostic errors in pediatric patients. There are patients' perspectives: First of all, I want to thank doctors for treating my child. When we visited the hospital with our four months baby, he had abdominal distension. After examination and various tests, the surgeon told us that they have to perform emergency surgery. After surgery, the doctor informed us that our child had a benign tumour which they have already removed. After twoyears post-surgery, our child is doing fine.

Contributors PK contributed to conceptualization and writing (original draft). AK contributed to conceptualization and writing (original draft). SC contributed to writing (original draft). NM contributed to conceptualization and data curation. GM contributed to data curation.

Funding The authors have not declared a specific grant for this research from any funding agency in the public, commercial or not-for-profit sectors.

Competing interests None declared.

Patient consent for publication Parental/guardian consent obtained.

Ethics approval Ethical approval was waived in view of retrospective nature of study.

Provenance and peer review Not commissioned; externally peer reviewed.

Data availability statement All data relevant to the study are included in the article or uploaded as supplemental information. All data relevant to the study are included in the article.
Open access This is an open access article distributed in accordance with the Creative Commons Attribution Non Commercial (CC BY-NC 4.0) license, which permits others to distribute, remix, adapt, build upon this work non-commercially, and license their derivative works on different terms, provided the original work is properly cited, appropriate credit is given, any changes made indicated, and the use is non-commercial. See: http://creativecommons.org/licenses/by-nc/4.0/.

ORCID iD

Arti Khatri http://orcid.org/0000-0002-6613-9705

\section{REFERENCES}

1 Ojili V, Tirumani SH, Gunabushanam G, et al. Abdominal hemangiomas: a pictorial review of unusual, atypical, and rare types. Can Assoc Radiol J 2013;64:18-27.

2 Vilgrain V, Boulos L, Vullierme M-P, et al. Imaging of atypical hemangiomas of the liver with pathologic correlation. Radiographics 2000;20:379-97.

3 Mansour S, Abofoul S, Bahouth H. Parietal peritoneal hemangioma mimicking acute appendicitis: a case report. Gen Surg Rep 2018;2:4.

4 George A, Mani V, Noufal A. Update on the classification of hemangioma. J Oral Maxillofac Pathol 2014;18:117-20.

5 Regula J, Wronska E, Pachlewski J. Vascular lesions of the gastrointestinal tract. Best Pract Res Clin Gastroenterol 2008;22:313-28.

6 Ernst L, Grabhorn E, Brinkert F, et al. Infantile hepatic hemangioma: avoiding unnecessary invasive procedures. Pediatr Gastroenterol Hepatol Nutr 2020;23:72-8.

7 Ilhan M, Oner G, Gök AFK, et al. Treatment of atypically-localized cavernous hemangioma in abdomen with atypical pain. Int $J$ Surg Case Rep 2016;25:24-7.

8 Khatri A, Mahajan N, Khan NA, et al. Kaposiform haemangioendothelioma of duodenum in a neonate. BMJ Case Rep 2021;14:e239527.

9 Rastogi K, Singh L, Khan NA, et al. Benign vascular anomalies: a transition from morphological to etiological classification. Ann Diagn Pathol 2020;46:151506. 